\title{
O PARTIDO DEMOCRATA CRISTÃO: TEORES PROGRAMÁTICOS DA TERCEIRA VIA BRASILEIRA (1945-1964)*
}

\section{The Christian Democratic Party: contents of the program of the Brazilian Third Way (1945-1964)}

\author{
Sandro Anselmo Coelho**
}

\begin{abstract}
RESUMO
Neste artigo analisamos como o Partido Democrata Cristão brasileiro, por meio de seu conteúdo programático, dava forma a sua proposta de Terceira Via; tratamos dos anos 1945/1954-1955, quando verificamos a maneira como o partido se portou em face dos limites daquela nascente democracia, e dos anos 1955/1963-1964, momento em que a sua Terceira Via adquiriu expressão eleitoral nacional.

Palavras-chave: Partido Democrata Cristão, democracia cristã, Terceira Via, partidos políticos, realinhamento do sistema partidário.
\end{abstract}

\begin{abstract}
In this article we discuss how Party Christian Democrat, through its programmatic content, gave form its proposal of Third Way; we analyze the years 1945/1954-1955, verifying how the party behaved before of the limits of that nascent democracy, and of the years 1955/1963-1964, moment in that its Third Way acquired national electoral expression.

Key-words: Party Christian Democrat, christian democracy, Third Way, brazilian political parties, realignment of the brazilian party system.

* Parte deste trabalho foi apresentada, sob o título A democracia cristã brasileira e seu programa, no XXI Simpósio Nacional da Associação Nacional de História, ocorrido em 2001, em Niterói, na Universidade Federal Fluminense. Além disso, registramos que este artigo tem por base um dos capítulos de minha dissertação de mestrado, a qual contou com uma bolsa do Conselho Nacional de Desenvolvimento

** Mestre em História pela Universidade Federal do Paraná.
\end{abstract} Científico e Tecnológico (CNPq). 


\section{Introdução}

Observando os estudos sobre a história política brasileira, notamos que os principais partidos políticos do período 1945/1964-1965 receberam muita atenção dos pesquisadores. Contudo, ressaltamos que são poucos os registros sobre o Partido Democrata Cristão (PDC), mesmo tendo sido este aquele que, percentualmente, mais cresceu no legislativo nacional entre 1954 e a edição do Ato Institucional n. ${ }^{\circ} 2$ (AI-2) em 1965. ${ }^{1}$

Diante deste quadro, resolvemos elaborar este artigo com o objetivo de analisar o conteúdo programático do PDC brasileiro, ou seja, identificar como ele apresentou, em diferentes conjunturas, sua proposta de Terceira Via. Nossa análise se desenvolverá indicando de que forma os programas partidários do PDC, de 1945 e de 1961, bem como os discursos dos pedecistas registrados nos Anais da Assembléia Constituinte de 1946 (AAC) e nos Anais da Câmara dos Deputados (ACD), ${ }^{2}$ respondiam aos dilemas pelos quais passou a política

1 Entre as tantas pesquisas sobre os partidos no período citamos: BENEVIDES, Maria Victoria de Mesquita. O PTB e o trabalhismo - partido e sindicato em São Paulo : 1945-1964. São Paulo : Brasiliense, 1989 ;

A UDN e o ud e Terra, 1985; PACHECO, Eliezer. O Partido Comunista Brasileiro: 19221964. São Paulo: Alfa-Omega, 1984; SAMPAIO, Regina. Adhemar de Barros e o PSP. São Paulo: Global, 1982. Quanto às pesquisas sobre o PDC, citamos uma tese de doutorado: BUSETTO, Áureo. A democracia cristã em São Paulo: princípios e práticas políticas. São Paulo: USP (mimeo.), 1998; um artigo: VIANNA, Luiz Werneck. O sistema partidário e o Partido Democrata Cristão. In: FLEISHER, David Verge (Org.). Os partidos políticos no Brasil. v. 1. Brasília: EDUNB, 1981 [1978 para o artigo de VIANNA]; além de um artigo e da dissertação de mestrado do autor do presente texto: COELHO, Sandro Anselmo. Democracia cristã e populismo: um marco histórico comparativo entre o Brasil e o Chile. In: Revista de Sociologia e Política, n. 15, Curitiba: UFPR, 2000; COELHO, Sandro Anselmo. O Partido Democrata Cristão (1945-1965): dilemas e inconsistências da terceira via brasileira. Curitiba: UFPR (mimeo.), 2002. As notas de Vianna, possivelmente pela impossibilidade de uma análise mais ampla de fontes coevas, acabam por dar indicações por vezes em demasiado genéricas e que nossa pesquisa não comprovou; exemplo disso são afirmações de que a proposição de Terceira Via do PDC "não se pautou pelo reformismo e, ademais, não se empenhou como um projeto modernizante, tendo cumprido um papel social praticamente inócuo" (VIANNA, op. cit., p. 135). Como veremos, o partido, principalmente a partir de meados dos anos 50, alinhou-se justamente em direção à modernização e às chamadas reformas de base. Além do que, Vianna entende que o PDC apenas desempenhou o papel político de uma espécie de UDN católica (p. 161), o que não se confirmou em grande parte do seu período de existência. O trabalho de Busetto busca, a partir da teoria sociológica de Pierre Burdieu, com seus conceitos de "campo", "capital" e "poder simbólico", investigar a dinâmica do PDC em São Paulo (BUSETTO, op. cit., p. 2-6); apesar deste trabalho trazer importantes e inéditas contribuições para o tema, entendemos que o autor não esgotou o assunto, pois o partido adquiriu importância nacional, não se restringindo a São Paulo. Quanto ao meu artigo, se insere nos marcos de minha pesquisa de mestrado, servindo de base para um dos capítulos da dissertação.

2 Tratemos de caracterizar os programas partidários e os discursos dos pedecistas na Câmara dos Deputados para os fins deste artigo. As versões dos programas do PDC utilizadas estão no livro: CHACON, Valmireh. História dos partidos brasileiros: discurso e práxis dos seus programas. Brasília: EDUNB, 1981. Entretanto, ressaltamos que elas foram conferidas com apresentações dos programas de 1945 e de 1961 . A 
brasileira. Será possível, assim, demonstrar a maneira pela qual os pedecistas ambicionaram ampliar as suas bases eleitorais. Tais programas e discursos permitem acessar como os pedecistas visaram responder a dois importantes dramas da nossa história política: a) pós-1945, quando "novas formas de governo teriam que substituir as medidas coercitivas do Estado Novo"; ${ }^{3}$ b) e início dos anos 1960, quando já se configurava uma alteração do sistema partidário nacional. Esta alteração foi assim entendida por Maria do Carmo Campello de Souza:

o declínio dos grandes partidos conservadores - UDN e PSD -, e a conseqüente dispersão eleitoral, induziram, em médio prazo, um processo de realinhamento do sistema partidário, e de fato já começaram a se configurar como tal. Os indícios deste realinhamento (...), eram bastante claros, e eram notados por uma minoria de observadores já no primeiro lustro dos anos cinquienta. (...) A alteração se dava em favor de pequenos partidos reformistas (PDC, PTN [Partido Trabalhista Nacional], PSB [Partido Socialista Brasileiro] e MTR [Movimento Trabalhista Renovador]). ${ }^{4}$

Antes de abordarmos o caso específico do PDC brasileiro, é pertinente uma aproximação introdutória sobre o tema da Democracia Cristã (DC) e de sua aspiração à Terceira Via. Desta forma, façamos uma brevíssima apresentação

primeira foi feita pelo padre Alfredo de Arruda Câmara, no Congresso Nacional em 15 de março de 1946; a segunda foi feita por André Franco Montoro, no Congresso Nacional em 19 de abril de 1961. Usamos a versão de Valmireh Chacon para facilitar o manuseio. Entendemos que os programas partidários do PDC ganham importância porque visavam, como de resto programas de partidos de uma maneira geral o fazem, expressar a forma como o partido se portava, ou se portaria, face a questões que julga relevantes, estando ou não no exercício do poder político institucional; expõem, portanto, quais são os projetos políticos de mais longo prazo dos seus membros. Sobre o papel que o programa representava para os pedecistas, ou seja, se os membros do partido eram ou não fiéis, é algo que averiguaremos neste texto. Quanto aos discursos utilizados, se encontram nos Anais da Assembléia Constituinte de 1946 ou nos Anais da Câmara dos Deputados, conforme o caso. São impressões oficiais do Congresso Nacional e foram acessados no Círculo de Estudos Bandeirantes, em Curitiba, Paraná. Apesar de não representarem, necessariamente, uma enunciação pública dos princípios de um partido, pois foram proferidos para um ambiente mais fechado, no caso a Câmara dos Deputados, do que os programas, os discursos nos possibilitam perceber as nuances com que cada agente político do partido explicitou, frente às diversidades do momento, os seus objetivos políticos, ou mesmo divergências sobre como atingir os objetivos comuns de mais longo prazo. Claro que tanto programas como discursos precisam ser inseridos no contexto histórico em que foram produzidos, pois é a ele que formulam respostas.

3 DREIFUSS, René Armand. 1964: a conquista do estado - ação política, poder e golpe de classe. Petrópolis: Vozes, 1981. p. 26.

4 SOUZA, Maria do Carmo Campello de. Estado e partidos políticos no Brasil: 1930-1964. São Paulo: Alfa-Omega, 1983. p. 43; ver também: A democracia populista, 1945-1964: bases e limites. In: ROUQUIÉ, Alain et al. (Orgs.). Como renascem as democracias. São Paulo: Brasiliense, 1985. p. 101. 
sobre a conformação da DC como alternativa política internacional a fim de propiciarmos ao leitor que porventura não conheça o assunto, a possibilidade de uma familiarização. Ao final da Segunda Guerra Mundial, a proposta democrata cristã surgiu como um movimento político autodenominado como distinto dos que até então se apresentaram no cenário político-partidário mundial. Esta alternativa passou a conquistar uma relativa força eleitoral em diversos lugares, em especial na Europa e na América Latina. Quanto à Europa, partidos democratas cristãos surgiram na Alemanha (União Democrata Cristã), na Itália (DC Italiana), na Áustria (Partido Popular), na Bélgica (Partido Social Cristão) e na França (Movimento Republicano Popular); observarmos, outrossim, partidos com esses princípios na Holanda (Partido Popular Católico) e na Suíça (Partido Conservador Suíço). Na América Latina, a DC esteve, para além do Brasil, no Chile, Argentina, Uruguai, Peru, Guatemala e El Salvador, todos com a denominação de PDC; no Paraguai (Movimento Democrata Cristão), na Nicarágua e na Bolívia (ambos como Partido Social Cristão), no Equador (DC Equatoriana), na República Dominicana (Partido Revolucionário Social Cristão) e na Venezuela (Partido Social Cristão - Comitê de Organização Política Eleitoral Independente). $\mathrm{O}$ ponto em comum entre estes diversos partidos esteve no fato de se apresentarem e se entenderem como diferentes das demais agremiações por formularem a idéia da chamada Terceira Via, a qual, resumidamente, se oferecia como alternativa entre o capitalismo liberal e a doutrina socialista revolucionária. Claro que esta proposta assumia características diferenciadas conforme o momento e a situação em que estava inserida. Mas a título de um registro mais amplo, vemos que os democratas cristãos a expunham como estando na "insistência sobre os valores familiares e sobre o papel das comunidades intermediárias, no respeito pela propriedade privada, na busca da participação nas relações de trabalho e no pluralismo político". 5

\section{Limites da democratização e primeiros momentos do PDC}

O PDC foi legalmente criado em 1945, mais especificamente a 9 de julho, no Teatro Municipal de São Paulo, portanto no limiar da ditadura de Getúlio Dornelles Vargas. Quem liderou esta ação foi Antônio Cesarino Júnior,

5 MAYEUR, Jean-Marie. Partidos católicos e democrático-cristãos europeus. In: BOBBIO, Norberto; MATTEUCCI, Nicola; PASQUINO, Gianfranco. (Orgs.). Dicionário de política. Brasília: EDUNB, 1999. p. 898. 
professor de Direito do Trabalho na Universidade de São Paulo. Além do pólo organizado pelo referido professor, o partido contou, no momento de sua fundação, com a fusão do pequeno Partido Popular, que era organizado a partir do Rio de Janeiro pelo jornalista Osório Lopes; este pequeno partido foi formado com motivações ligadas ao sucesso da Terceira Via na Itália, resultante do desempenho eleitoral da DC no pós Segunda Guerra. Outro agrupamento que se fundiu ao PDC por aquele período foi o embrião do Partido Republicano Democrático que "formando-se a partir de São Paulo, era composto por um reduzido número de membros [que] mantinham vínculos de amizade com lideranças do Partido Popular, o que favoreceu a sua agregação ao PDC". ${ }^{6}$ Como elemento unificador desses grupos, grosso modo, estavam a sua aproximação aos pressupostos da Terceira Via democrata cristã e a pretensão de tornarem-se galvanizadores das reservas de energia da Igreja, bem como transmitir estas reservas a amplos setores sociais.

O discurso de Manuel Vitor de Azevedo, deputado constituinte eleito pelo PDC paulista, ${ }^{7}$ na primeira sessão da Assembléia Constituinte, a 6 de fevereiro de 1946, é demonstrativo dessa busca em representar os anseios de um eleitorado que, aos olhos destes políticos, definiria seu posicionamento eleitoral por conta de sua posição religiosa. Diante desse quadro, disse o deputado a seus colegas: "trago-vos a representação legítima de milhares de católicos. (...) Minha missão continua, agora, no propósito de cristianizar a lei”. Na nossa compreensão, era a busca desta galvanização, como capital político, o caminho mais plausível para quem não encontrava espaço nos grandes partidos daquele período, dada a própria dinâmica do processo eleitoral existente. Afinal, à época, o PSD tinha um razoável controle sobre as classes subalternas camponesas, o PTB vinha se apoiando nas classes populares urbanas, e a UDN articulava praticamente todos os oposicionistas àquele modus operandi do sistema partidário brasileiro. ${ }^{8}$

Para lançarmos mais luz sobre este momento, vemos relevância na discussão sobre aquele problemático contexto político nacional. Diríamos que

6 BUSETTO, op. cit., p. 64.

7 O outro deputado constituinte pedecista foi o então presidente nacional do partido, Arruda Câmara, eleito em Pernambuco. Uma boa referência à atuação política destes dois constituintes, bem como dos demais, é a dissertação de mestrado: BRAGA, Sérgio Soares. Quem foi quem na Assembléia Constituinte de 1946: um perfil socioeconômico e regional da Constituinte de 1946. São Paulo: Unicamp (mimeo.) 1996.

8 Adotamos, por sistema partidário, o entendimento de Campello de Souza: o sistema partidário "delineia como objeto de interesse o conjunto de relações dos diversos partidos entre si, com o corpo eleitoral e com os grupos de interesse, por um lado, e com os diversos aparatos que compõem o Estado, em sentido estrito, por outro" (SOUZA, Maria do Carmo Campello de. Estados e partidos... p. 43). 
é fundamental ter em conta que, apesar da ditadura de Vargas ter conseguido, até 1945, impedir o surgimento de partidos políticos, este seu propósito não logrou uma longa duração. Afinal, um modelo de Estado que, para muitos, era facilmente identificável com o fascismo, possuía, depois da vitória dos Aliados na Segunda Guerra Mundial, cada vez menos condições de se manter. Isto se dava, em alguma medida, porque este Estado, forçosamente ou não, havia enviado tropas para combater ao lado das potências democráticas liberais capitalistas, justamente contra o totalitarismo europeu. Todavia, o fim da ditadura varguista deveria, na ótica dos que apoiavam o Estado Novo, ser cuidadosamente orquestrado e não se dar ao ritmo de uma música que poderia comprometer o exercício de seu poder político. As possibilidades de organização popular, que davam já os seus acordes, e num tom que não agradava aos ouvidos de uma elite política acostumada a impor seus projetos de forma autoritária, eram vistas como uma real ameaça. A partitura, a muito custo, foi elaborada:

"O descontentamento popular deveria ser esvaziado, absorvendo sua liderança e tentando conseguir uma burocratização de suas demandas através de instrumentos de repressão pacífica, como aqueles fornecidos pelo Estado patrimonial e cartorial". ${ }^{9}$ Portanto, antes de deixar formalmente o Executivo, os estadonovistas procuraram compor uma disciplinada harmonia que buscou controlar algum possível processo de aprofundamento da politização da sociedade brasileira, o que seguramente traria limites para as margens de manobra política dos setores populares. Em certo sentido conseguiram seu intento, vide a pouca alternância do poder no período, pois o PSD e o PTB apenas saíram do Executivo federal no governo Jânio Quadros, ou seja, por pouco mais de seis meses. Para atuar nestes imbricados acontecimentos ligados à abertura democrática, os agentes políticos vinculados ao Estado Novo tentaram

9 DREIFUSS, op. cit., p. 26. Na mesma linha interpretativa temos Campello de Souza: "o advento do pluralismo partidário, de eleições diretas, e o retorno à separação formal dos poderes do Estado, determinados pela Carta Constitucional de 1946, foram superpostos ou acoplados à estrutura anterior, marcada pelo sistema de interventorias, por um arcabouço sindical corporativista, pela presença de uma burocracia estatal detentora de importante capacidade decisória, para não mencionar a plena vigência na quadra histórica a que nos referimos, de uma ideologia autoritária do Estado" (SOUZA, Maria do Carmo Campello de. Estado e partidos..., p. 106. Ver também: A democracia populista..., p. 91-92). Candido Mendes conclui algo que se aproxima disso: "O Estado Novo invade o nosso imaginário social num corte assumido com as instituições anteriores" (MENDES, Candido. A democracia desperdiçada: poder e imaginário social. Rio de Janeiro: Nova Fronteira, 1992. p. 53). Fernando Luiz Abrucio considera, para o período, que "a Presidência se tornou o centro nevrálgico da estrutura burocrática que dava suporte ao estado desenvolvimentista, tendo grande importância na coordenação da arena decisória governamental" (ABRUCIO, Fernando Luiz. Os barões da federação: os governadores e a redemocratização brasileira. São Paulo: Hucitec; Departamento de Ciência Política; USP, 1998. p. 49). 
estabelecer "um esquema de limitada mobilização política nacional das massas urbanas, baseado em uma estrutura sindical controlada pelo Estado e no apoio institucional do PSD e do PTB". ${ }^{10}$ Nessa quadra histórica de pouca mobilidade foi que o PDC procurou espaço para solidificar sua proposta de Terceira Via, e, portanto, não nos admira que tenha demorado até o início dos anos 60 para adquirir alguma expressividade entre os eleitores em nível nacional.

Outro elemento que dificultava um melhor tônus eleitoral da Terceira Via do PDC foi a negativa da Igreja Católica em apoiar este partido. Afinal, "a maioria do bispado, ciosa de sua autoridade, opunha-se a ligação da Igreja ao nascente PDC, temendo que o partido, com seu possível crescimento, viesse desafiar e comprometer a sua posição hierárquica" ${ }^{11}$ Além do que, a cúpula do clero brasileiro pareceu estar mais interessada em se ligar com forças mais conservadoras do que com um agrupamento vinculado à Terceira Via, o qual poderia, como de fato ocorreu, ganhar um sentido fortemente reformista, comprometendo as relações eclesiásticas com as elites políticas dominantes. Quanto às eleições, a estratégia da Igreja Católica foi por meio da Liga Eleitoral Católica (LEC), com a qual se procurava estar fora e acima dos partidos, apoiando, é claro, candidatos de diversas agremiações e que se comprometessem com as posições do alto clero. ${ }^{12}$

Sendo assim, o número de pedecistas que atingiu o Congresso Nacional, enquanto não se abriram novas possibilidades na vida política nacional, não pôde ser significativo. Na legislatura de 1946-1951, foram dois deputados eleitos: Arruda Câmara, por Pernambuco, e Manuel Vitor de Azevedo, por São Paulo. Para os trabalhos legislativos federais entre 1951-1955, os pedecistas eleitos foram três: permaneceu o padre pernambucano, por São Paulo elegeu-se Auro Soares de Moura Andrade e pelo Amazonas, André Vidal de Araújo; entretanto, já indicando o realinhamento, Antenor Mourão Bógea, eleito pela UDN no Maranhão, anunciou sua filiação ao PDC em 19 de fevereiro de 1954 e, vindo do PTB da Bahia, Joel Presídio de Figueiredo indicou, a 2 de fevereiro de 1954, a sua entrada no PDC, acompanhado por outros deputados estaduais baianos.

10 DREIFUSS, op. cit., p. 27. A respeito disso, Campello de Souza assim se posiciona: "A estrutura partidária formou-se em grande medida por decisão governamental, estruturando-se em função de fatores marcadamente conjunturais (anti ou pró-varguismo) e não por clivagens sócio-econômicas nítidas" (SOUZA, Estado e partidos políticos... p. 41-42; ver também: BENEVIDES, O PTB e o trabalhismo..., p. 31.

11 BUSETTO, op. cit., p. 60.

12 CARNEIRO JÚNIOR, Renato Augusto. Religião e política: a Liga Eleitoral Católica e a participação da Igreja nas eleições de 1932-1954. Curitiba: UFPR (mimeo.), 2000, p. 99; ver também: VIANNA, op. cit., p. 138 . 
Assim, os pedecistas contaram, ao final desta legislatura, com cinco cadeiras federais.

Naquele quadro de institucionalização do pluripartidarismo, os pressupostos dos pedecistas mantiveram-se em sintonia com aqueles que pretendiam reorganizar o sistema político brasileiro, ou seja, postados contrários a muito do que o Estado Novo representava. Num momento em que era apreciável a defesa de uma maior abertura nos meios decisórios do Estado brasileiro, não poderia faltar no elenco das reivindicações do PDC, em seu programa de 1945, os seguintes pontos:

elaboração, pelos representantes legítimos do povo brasileiro, de uma nova Constituição em moldes inteiramente democráticos; (...) supressão do Departamento de Imprensa e Propaganda, dos Departamentos Estaduais de Imprensa e Propaganda, do Tribunal de Segurança Nacional e revogação das leis de opressão.

Entre seus principais fundamentos não faltariam questões que se contrapunham a elementos ditatoriais do estado-novismo. Nesse sentido, pregavam o

sufrágio universal, com a maior amplitude, de modo a fazer dos governadores a expressão real do consentimento dos governados; a autonomia e respeito recíproco rigoroso dos Poderes Legislativo, Executivo e Judiciário, sem que nenhum ultrapasse os limites dos seus direitos e o governo seja a expressão da harmonia entre eles e não da proeminência do Poder Executivo, como vem se dando no Brasil há muito tempo. ${ }^{13}$

A própria data e local escolhidos para a fundação do partido são indicativos do teor dos pressupostos que os pedecistas pretendiam dar a sua política.

A saída de Vargas da administração do Estado foi tão importante para os pedecistas que chegou a ser entendida como um marco de datação que traria de volta a normalidade para a história nacional; demonstra isso a afirmação de que havia chegado "o momento em que o país retoma o ritmo de sua evolução histórica normal". Assumindo tal postura, tivemos Arruda Câmara assim se referindo a este fato, a 6 de fevereiro de 1946: "Nesta alvorada luminosa que

13 O 9 de julho é a data em que os paulistas comemoram o movimento de insurgência contra Vargas, ocorrido em 1932, o qual é chamado de Revolução Constitucionalista. 
inicia uma nova era, assistimos a vitória do Direito sobre a força; a afirmação do primado do espírito sobre a matéria e a exaltação da liberdade e da democracia, que se erguem sobre os escombros das ditaduras". E nessa contracorrente a Vargas, o grupo aqui estudado só poderia destacar como elemento positivo, e que adviesse da administração varguista, algo que se ligasse umbilicalmente aos seus interesses. É com essa perspectiva que vemos suas observações programáticas acerca do ensino religioso; para o PDC, "uma das poucas conquistas da opinião pública nacional, incorporadas desde 1931 à legislação do Estado" foi a inclusão, nas escolas, do ensino religioso facultativo como matéria de programa e de horário. Vemos, nisto, e com limpidez, mais elementos de sua pretensão de se tornar o partido galvanizador das energias políticas da Igreja Católica.

Provavelmente este antivarguismo do PDC - muito compreensível num contexto em que se livrar de Vargas significava, para muitos, efetivar mudanças que não fugissem ao seu controle - tenha contribuído para que o estudo de Benevides assinalasse que o partido fosse um simples satélite da UDN. ${ }^{14}$ Contribui para este ponto de vista, por exemplo, ainda que seja uma interpretação que não valoramos como fonte primária, a recente declaração de um dos agentes políticos do período, o ex-governador pedecista do Paraná, Ney Aminthas de Barros Braga; para ele, seus correligionários estiveram, durante o governo de Juscelino Kubitschek de Oliveira, "aproximados da linha de atuação de Carlos Lacerda", ${ }^{15}$ o prócere udenista e talvez o maior adversário do varguismo. Outro dado que indica o antivarguismo de notórios membros do PDC foi o fato de nenhum deles, quando da comoção nacional pelo suicídio deste Presidente da República, a 24 de agosto de 1954, haver sequer pedido a palavra na Câmara Federal, em sessão específica sobre o assunto, para expressar alguma posição. Pelo que dissemos, ficou expresso que os pedecistas viram a necessidade de modificar o sistema político nacional que havia sido constituído

14 BENEVIDES, A UDN e o udenismo..., p. 224; 228. Essa noção do PDC como satélite da UDN provavelmente tem sua origem no trabalho: SOARES, Gláucio Ari Dillon. Sociedade e política no Brasil: desenvolvimento, classe e política durante a Segunda República. São Paulo: DIFEL, 1973. Nele, se faz referência ao partido: "Minha interpretação é a de que o PDC recrutou principalmente eleitores que seguiam, ou pensavam seguir, uma orientação característica dos clássicos partidos liberais e que poderia ter dado seus votos à UDN" (SOARES, op. cit., p. 92). Tendo em peso que este autor identifica no Brasil uma diferenciação entre regiões desenvolvidas e subdesenvolvidas como forma de explicar diferentes culturas políticas (p. 150213), e que Paraná e São Paulo, estados onde o PDC teve o seu maior crescimento, e segundo ele, são partes desenvolvidas do país, é curiosa a pouca importância dada ao crescimento deste partido nestes estados. Sobre o papel do PDC à época ver também: BENEVIDES, O PTB e o trabalhismo..., p. 32; e VIANNA, op. cit., p. 159.

15 BRAGA, Ney Aminthas de Barros. Ney Braga: tradição e mudança na vida política paranaense: Entrevista a Adherbal Fortes de Sá Júnior. Curitiba: Editora do Autor, 1996. p. 94. 
pelo Estado Novo. Todavia, as transformações, na sua ótica, precisavam ser ordenadas de forma a não colocar em xeque uma parcela significativa do ordenamento político-institucional: para eles cada peça deveria ter o seu lugar no tabuleiro de forma a não colocar em risco a ordem social. Bem sintonizados com a elite política que ambicionava direcionar os rumos da abertura democrática, os pedecistas sentiam a necessidade de, naquela conjuntura específica, limitar, por assim dizer, a ação dos peões num momento em que a mobilização popular e alguma forma de democratização precisavam se articular a fim de impedir que o jogo fosse além da simples disputa entre peças brancas e pretas. O programa do PDC de 1945 indicava os limites almejados: "essa ascensão das massas e essa instauração da democracia podem operar beneficamente, se repousada sobre uma base ética racional e evangélica"; ou seja, nada de peões tomando a torre e os cavalos, ou ficando contra o rei, a rainha e, no caso específico do PDC, muito menos contra o bispo. Na perspectiva do partido, a participação política popular e a própria democracia que, de uma forma ou de outra, ainda que aos tropeços, dava seus passos, apenas teriam um caráter positivo se condicionadas à existência de um ordenamento evangélico em nossa sociedade. Vemos este condicionamento que vincula democracia com religião como muito perigoso, posto que o mundo da devoção certamente não é o ambiente mais propício para a discussão ampla, como requer um processo político que possua, ou venha a querer possuir, alguma possibilidade de disputa franca e aberta.

O próprio ordenamento social que os pedecistas julgavam conveniente para o nosso país certamente surpreenderia muitos pelo seu caráter profundamente limitador. Para eles, como expunha o programa de 1945, "a ordem social se baseia na ordem jurídica e a ordem jurídica na ordem moral". E caso se inverta a hierarquia deste ordenamento, o que poderia ocorrer? O partido responde: "está aberto o caminho à instituição de todas as ditaduras e à subversão da ordem natural da sociedade". Outra exposição de Arruda Câmara, feita em 5 de abril de 1946, nos dá a dimensão do porquê da adoção de pressupostos tão engessados sobre a resolução dos problemas sociais. Para o deputado:

seria desastroso pensar que a crise pode ser vencida sem que a calma e a ordem públicas prevaleçam. A história está cheia de exemplos de massas famintas levadas à desordem e à pilhagem. Procurar conjurar a crise em meio aos distúrbios, seria o mesmo que tentar semear os campos com brasas acesas. Ai daqueles que ateiam ou incendeiam agitando revoltas infrutíferas. 
Tudo nos leva a crer que o grande temor dos pedecistas era, naquela conjuntura de abertura democrática, que as massas populares passassem a se organizar de tal forma que colocassem em risco o ordenamento político.

Tendo em peso essas constatações, fica explícito qual seria o conteúdo da democracia e da participação popular que os pedecistas viam como necessários para que a sociedade seguisse sua normalidade. Para que as coisas funcionassem de forma condizente aos seus preceitos, precisaríamos que a evangelização fosse a estrutura que sustentasse a sociedade, bem como que a moral fosse o seu marco ordenador; não esqueçamos a missão que Manuel Vitor entendia como sua na Constituinte de 1946, a de cristianizar a lei. Como pudemos detectar, os pressupostos pedecistas estavam ligados com as necessidades da elite política dominante de buscar estabelecer uma democracia sob o máximo controle e disciplina possíveis. Para os correligionários do PDC, isso representava instituir algo hierarquizado tão do alto que poderíamos dizer que só poderia ocupar o seu topo quem estivesse no céu. Essa noção estaria muito perto do corporativismo autoritário que Busetto indica estar presente em muitos dos fundadores da DC na América Latina. ${ }^{16}$ Referenda mais estas nossas considerações, o forte anticomunismo do principal líder do PDC neste período, Arruda Câmara, que, para além do discurso, não teve dúvidas de defender a extinção do Partido Comunista Brasileiro (PCB). Não era para menos se, afinal, como disse ela a 27 de março de 1946, "o Diabo era comunista", e tal companhia parlamentar não lhe agradaria.

Entendendo que o PDC foi fundado num momento em que rupturas e continuidades se entrecruzavam na forma pela qual a política brasileira se dedicava a resolver as demandas dos diversos setores sociais, vemos que, no campo econômico, onde as premissas da Terceira Via teriam mais chances de ser observadas, os pedecistas se postaram ambíguos programaticamente. Ora apresentavam-se claramente liberais - portanto, bem situados como satélites do baluarte do liberalismo brasileiro pós 45 , qual seja, a UDN - e ora davam indícios da necessidade de intervenção estatal no mundo do homus economicus.

Eram notadamente liberais quando expressavam no programa que "o Estado, economicamente, tem funções supletivas, não podendo intervir diretamente na gerência das atividades econômicas particulares, a não ser

16 BUSETTO, op. cit., p. 16;22. Confirma esta linha bastante conservadora do PDC, por exemplo, o fato de ser Arruda Câmara o autor da "emenda [constitucional] (sem número) estabelecendo a necessidade de prévia e justa indenização em dinheiro em caso de desapropriação por interesse social (emenda aprovada)" (BRAGA, op. cit., p. 378, com grifos no original). Esta emenda foi foco de inúmeras discussões no início dos anos 60 . 
quando por estas solicitado e a título temporário". No que se refere à política econômica internacional, deveria-se "evitar todo exagerado protecionismo nacionalista". Estas seriam, outrossim, maneiras de se postar contra alguns entendimentos centrais do varguismo. Os seus posicionamentos programáticos acerca do liberalismo econômico não eram apenas parte de uma retórica que seria esquecida quando o programa fosse registrado oficialmente. Quando o deputado Paulo Sarasate, da UDN, apresentou um projeto que visava congelar os preços de aluguéis devido à crise econômica pela qual o país passava, Arruda Câmara foi enfático, em 23 de maio de 1946, ao dizer que o deputado udenista "não pode esquecer os sagrados direitos dos proprietários. (...) O que se está fazendo neste caso é demagogia". O Estado, não poderia, por esta perspectiva, cercear a liberdade dos especuladores imobiliários de manter sua lucratividade sobre aqueles que pagavam aluguel. Podemos dizer, portanto, que a atuação da empresa privada, bem como a defesa da inviolabilidade do uso da propriedade particular, eram entendidas como um campo aberto em que o livre mercado iria, a primeira vista, gerir seu funcionamento. Mesmo o capital multinacional, fonte de tanta discussão no período, poderia atuar no país sem muitos problemas. A administração pública seria chamada apenas quando a iniciativa privada achasse conveniente e, porque não dizer, lucrativo.

Se, por um lado, o PDC defendeu a livre empresa, por outro, expunha a necessidade de intervenção do Estado na economia, aí se aproximando mais da Terceira Via. Os pedecistas pensavam que não era contraditório conciliar os pressupostos liberais que expusemos acima com a pretensão programática de que houvesse "um limite de lucros" e que seus excessos seriam controlados "de acordo com as leis da justiça e da eqüidade". Contudo, parece extremamente duvidoso imaginar que os empresários vão chamar o Estado para controlar seus lucros, como, basicamente, parece ter sido a receita do PDC.

Cabe salientar que, mesmo tendo em mente os já indicados dualismos do seu programa de 1945, os pedecistas estiveram entre os políticos que à época melhor conseguiram elaborar, um posicionamento mais definido, ainda antes da reformulação programática, quando a sua Terceira Via, então, ficou mais palpável. Confirma essa constatação, por exemplo, o fato de Arruda Câmara haver oferecido, em 15 de março de 1946, o programa do PDC, em sua ordem econômica e social, como contribuição à Assembléia Constituinte; ou ainda, em estrita ligação com este programa, suas recorrentes defesas do casamento monogâmico e indissolúvel, bem como do efeito civil do casamento religioso, da família como base da reconstrução social do país, do ensino religioso facultativo nas escolas, da assistência religiosa para as classes armadas em caráter permanente. 
A partir dos elementos que coletamos, no que se trata ao objetivo clássico da DC, qual seja, constituir uma Terceira Via ao capitalismo e ao socialismo, notamos que entre os anos 1945 e 1954-1955, essa proposta não esteve muito clara entre os pedecistas brasileiros, se formos ter em mente a articulação entre o programa e os discursos. Apenas expressavam, e de forma muito tímida, a necessidade de controle dos lucros das empresas.

\section{O realinhamento programático: fortalecimento da terceira via pedecista}

Com o intuito de melhor nos dedicarmos ao conteúdo programático pedecista e, assim, a seu pressuposto de Terceira Via no contexto de 1961, é conveniente tomarmos duas providências. A primeira é situar a dimensão intrapartidária do PDC, a fim de percebermos de onde vinham as propostas de mudanças que permitiram ao partido adquirir, no cenário nacional, a partir de meados já dos anos cinqüenta, um maior dinamismo político. Sendo assim, ganha sentido a segunda providência: buscar inserir este maior dinamismo no já citado processo de realinhamento do sistema partidário, que, no nosso entender, contribuiu decisivamente nas modificações programáticas feitas pelos pedecistas. Destacamos, portanto, que seus programas apresentavam fundamentos que não se restringiam a apenas cumprir uma formalidade legal. A própria atitude de mudança do programa confirma isso, demonstrando a importância que lhe davam, pois se isso não tivesse relevo para os partidários da Terceira Via, para que gastar tempo em modificá-lo? Além do que, a reformulação nos remete ao fato dos correligionários do PDC perceberem que, para um melhor desempenho eleitoral num quadro bastante diverso de 1945, era pertinente e possível dar maior concretude a sua Terceira Via, o que tornaria a DC brasileira mais afinada com suas congêneres internacionais.

A situação política nacional começou a adquirir novos tons com o acirramento do debate político e econômico. Nesse ínterim o PDC conseguiu, no âmbito do legislativo federal, tornar-se o partido que mais cresceu percentualmente entre 1954 e 1962, pulando de três para vinte e uma cadeiras, contando com um senador. Este processo pode ser observado, como vimos, ainda no início de 1954, quando a bancada pedecista passou de três deputados para cinco, aumentando significativamente. 
Para compreendermos a mudança de rumo do partido, importa destacar que, em meados da década de cinquienta, o PDC contou em seus quadros com importantes militantes vindos de um agrupamento oriundo de São Paulo, a Vanguarda Democrática (VD): ${ }^{17}$ tais militantes contribuíram decisivamente na alteração programática, a qual deu um caráter mais preciso para a Terceira Via pedecista. A VD era composta por democratas cristãos fundamentados no pensamento de Jacques Maritain ${ }^{18}$ e que mantinham relações com outros correligionários na América latina, daí ter buscado dar um caráter mais programático à sua ação partidária. Era formada por militantes católicos que atuaram em organizações como a Ação Católica Brasileira e a Juventude Universitária Católica (JUC). Contava com figuras como Franco Montoro, Antônio Queiroz Filho, Plínio Santos de Arruda Sampaio, Chopin Tavares de Lima, João Baptista de Arruda Sampaio, Teófilo Ribeiro de Andrade Filho, Eduardo Bastos, Luís Melo, Nadir Gouveia, Helena Junqueira, Odilon da Costa Manso e Clóvis Garcia. Dentre estes componentes, Franco Montoro participou em abril de 1947, em Montevidéu no Uruguai, do I Congresso da Democracia Cristã na América. "Neste evento, militantes e políticos católicos latinoamericanos, reunidos por iniciativas pessoais, elaboraram uma estratégia de ação conjunta para a extensão da 'Terceira Via' na América Latina". ${ }^{19}$ Com o passar do tempo este grupo, liderado por Franco Montoro e Antônio Queiroz Filho, decidiu ingressar no PDC como forma de melhor dinamizar os recursos para que suas propostas fossem transformadas em ações políticas concretas.

17 Um bom quadro sobre a VD está em: BUSETTO, op. cit., p. 33-55. O autor chega a diferenciar pedecista e democrata cristão. Para ele "o pedecista devia seu ingresso e muitas vezes sua permanência nas fileiras do PDC ou nelas se mantinha exclusivamente por interesse em dispor de uma legenda partidária para disputar eleições, utilizar-se da estrutura do partido para se posicionar melhor na troca de apoio com lideranças de outras agremiações por benefícios pessoais. Não apresentava nenhum compromisso ou contribuição com o projeto de aplicação e adaptação das propostas democratas cristãs à realidade brasileira". O democrata cristão "estava comprometido com o trabalho de desenvolvimento da Democracia Cristã no Brasil, disposto a manter uma ação permanente e não restrita às câmaras legislativas, procurava discutir e elaborar conjuntamente com seus pares respostas fundamentadas no caldo doutrinário-ideológico da 'Terceira Via' aos problemas da realidade nacional" (p. 96-97). Os fiéis representantes da DC no PDC seriam, nesta perspectiva, os membros advindos da VD ou a ela estreitamente ligados. Para nós, entretanto, um ponto em comum que existe em todos os aderentes do partido era sua disposição em se vincular, seja por convicção, seja por viabilidade eleitoral, às propostas de Terceira Via, o que, de uma forma ou de outra, acabava por fortalecer estes pressupostos.

18 Católico convertido do protestantismo, Jacques Maritain (1882 - 1973) nasceu na França. Em 1936, publicou Humanismo integral; em 1943, Cristianismo e democracia; em 1944, Princípios de uma política humanista; e em 1959 O homem e o estado. Suas obras fundam muitas propostas políticas da Terceira Via da DC. Uma análise sobre seus pressupostos pode ser encontrada em: SOUZA, Rogério Luiz de. A reforma social católica e o novo limiar capitalista (1945-1965). Curitiba: UFPR (mimeo.), 2001. p. 33-77.

19 BUSETTO, op. cit., p. 12. 
Quanto ao quadro político-partidário mais geral, é relevante uma reflexão sobre alguns problemas com os quais se deparava a elite política. No início da década de sessenta, muitos temas controversos entraram na agenda política nacional, forçando os partidos a assumir posições ideológicas mais claras, como foi o caso do próprio PDC e de sua Terceira Via. Este processo é mais facilmente apreendido se voltarmos nossos olhos um pouco mais para trás no tempo. Não esqueçamos que a administração pública federal, ainda nos anos cinqüenta, dava sinais de que não podia responder de forma estável às diversas demandas sociais. A respeito desse problema, René Armand Dreifuss expôs o seguinte:

no final da administração de Kubitschek ficou claro que o seu "modelo de desenvolvimento", apesar de suas realizações, havia se esgotado, o próprio governo admitiu implicitamente esse fato adotando ostensivamente uma política de "adiamento dos problemas". O adiamento tático era visível, visava transferir para a administração seguinte os problemas que se acumulavam sem serem resolvidos. ${ }^{20}$

No interior deste drama político, os pedecistas passaram a ser mais aceitos pelo eleitorado. Tal crescimento é entendido se o relacionarmos, também, com um processo pelo qual passou a economia brasileira e que é classicamente entendido como de associação com o capital monopolista internacional. A síntese deste processo está na Instrução 113 da Superintendência de Moeda e do Crédito (Sumoc), baixada no início de 1955, na Presidência de Café Filho. Como aponta Ricardo Maranhão, tal Instrução

permitia investimentos estrangeiros diretos sem cobertura cambial, assegurando ao investidor estrangeiro a importação de equipamentos industriais segundo uma classificação prioritária dada pelo governo. Mantida esta tendência no período Kubitscheck, ela obrigaria os

20 DREIFUSS, op. cit., p. 37; ver também: SANTOS, Wanderley Guilherme dos. Sessenta e quatro: anatomia da crise. São Paulo: Vértice, 1986. p. 39. 
industriais brasileiros a se associarem a estrangeiros, abrindo a estes uma ampla gama de facilidades. ${ }^{21}$

Era a economia brasileira abrindo suas portas para a associação com o capital monopolista internacional. Na medida em que este acontecimento tomava maiores proporções, mais acirradas se tornavam as disputas pelo exercício de poder institucional, mais instável o quadro político ficava e mais os pedecistas iam tendo brechas para apresentar sua Terceira Via.

No processo de modificação do quadro partidário, mais precisamente com o resultado das eleições de 1962, é interessante ressaltarmos que os três maiores partidos, que haviam obtido, em 1945, 78,7\% dos votos, receberam, dezessete anos mais tarde, somente $38,9 \%$ deles, enquanto alianças partidárias obtinham $41 \%$. Por outro lado, o número de votos em branco subiu de 468.000 (4,8\%) em 1954 para 2.149.111 (15\%) em 1962. AUDN passou de 26,3\% em 1945 para $11,2 \%$ em 1962, o PSD de 42,3\% para $15,6 \%$ e o PTB de $10,1 \%$ para $12,1 \%$. Desta forma, num período em que os três maiores partidos passaram, em conjunto, a representar eleitoralmente muito menos do que logo após a Segunda Guerra Mundial - portanto, quando o ordenamento político formado para a saída de Vargas se demonstrava ineficiente para manter a estabilidade - foi que os pedecistas conseguiram obter mais espaço para expressar sua Terceira Via.

Nessa quadra histórica, as idéias do grupo vindo da VD puderam ser melhor posicionadas no PDC. Na medida em que propostas como lei antitruste, reforma agrária, reforma eleitoral, defesa de relações diplomáticas e comerciais com todos os países e sindicalização rural iam ganhando mais corpo no interior do partido, mais tons reformistas ele adquiria, ${ }^{22} \mathrm{e}$ mais a sua Terceira Via tomava feições que lhe possibilitava um maior acesso aos eleitores.

21 MARANHÃO, Ricardo. Estado e política "populista” no Brasil (1954-1964). In: FAUSTO, Boris. (Org.). História geral da civilização brasileira. São Paulo: Difel, 1986. p. 264. v. 9, t. III: O Brasil republicano (1930-1964). Um importante estudo sobre o governo presidencial de Kubitschek é: BENEVIDES, Maria Victoria de Mesquita. O governo Kubitscheck: desenvolvimento econômico e estabilidade política (1956-1961). Rio de janeiro: Paz e Terra, 1976, onde a autora problematiza acerca do quadro político do período, sendo que, para ela, "a estabilidade política do Governo Kubitschek foi fruto de uma conjuntura especial na qual as Forças Armadas e o Congresso atuaram de maneira convergente apoiando a política econômica cujo núcleo era o Programa de Metas" (p. 248).

22 Áureo Busetto assim se refere ao novo contorno programático do partido: "Se tal definição dos aderentes/eleitores mobilizados pela representação de mundo social democrata cristão não possibilitava posicionar o grupo e o PDC paulista como forças políticas populares, ela permite a definição do movimento democrata cristão como uma força agregadora e representante de interesses e demandas reformistas e democráticas de segmentos da sociedade civil brasileira da época” (BUSETTO, op. cit., p. 162-163). 
Diante desses eventos, os pedecistas, buscando se atualizar para atingir uma maior densidade eleitoral, modificaram o seu programa partidário. Era o momento de readequar suas propostas para o novo contexto; as alterações se concretizaram na Convenção Nacional do PDC, realizada em Curitiba, nos dias 8 e 9 de abril de 1961. Na Convenção, três linhas se confrontaram. Uma, estritamente conservadora, liderada por Arruda Câmara e Juarez Távora visava centrar o partido na luta pela moralização dos processos da administração pública e na defesa de um vago bem comum; já pudemos ver seu caráter anticomunista e avesso a reformas. Outra, mais propensa às reformas, liderada por Paulo de Tarso Santos, Plínio de Arruda Sampaio e contando com o apoio da Juventude Democrata Cristã (JDC), objetivava dar um ar antiimperialista para a Terceira Via do partido, defendendo o nacionalismo econômico; pregava a reforma agrária e reformas sociais mais ampliadas que melhorassem a condição dos trabalhadores urbanos e rurais. ${ }^{23}$ Destacamos que, no final de 1961, a 9 de outubro, Paulo de Tarso Santos expôs na Câmara dos Deputados uma proposta radicalizada feita à direção do PDC: modificar o nome do partido "para Partido Socialista Cristão, expressão mais adequada a uma agremiação que se deve voltar a realizar a socialização defendida corajosamente pela Encíclica Mater et Magistra"; para este deputado, "a sobrevivência e a dignidade eram prioridades em relação ao direito de propriedade". Um terceiro grupo, liderado por Antônio Queiroz Filho e Franco Montoro, se apresentava como aberto às reformas, mas distante tanto do anticomunismo como de uma pretensa busca do socialismo. Acabou servindo como agente conciliador da Convenção, permitindo que a formulação da Terceira Via do PDC acomodasse um pouco do afã de cada uma das tendências.

Nesse contexto encontramos indícios para compreendermos porque, a partir daí, ficou mais explícita, no programa do PDC, as propostas de Terceira

23 Salientamos que este era o grupo intrapartidário mais afinado com as chamadas reformas de base, as quais entraram, durante o governo de João Belchior Goulart, na agenda política brasileira de uma forma decisiva para o futuro daquela democracia. Segundo Edgar Carone, "por Reformas de Base entende-se a questão da reforma agrária, a reforma sindical, a reforma bancária, as reformas Constitucional Político-Partidária Eleitoral, a reforma Tributária Federal, o Plano Contra a Inflação, o Plano Trienal do Governo, a Auto-suficiência Alimentar no Brasil, o Programa para a Produção de Energia, a Eletrificação Ferroviária, a Defesa dos Preços dos Produtos Exportáveis, a Dinamização da Zona Livre de Comércio e a Reorganização da Marinha Mercante" (CARONE, Edgar. A república liberal II: evolução política (1945-1964). São Paulo: DIFEL, 1985, p. 191192, Entretanto, a posição em defesa das reformas de base não era exclusividade deste grupo intra-PDC, como demonstra o discurso de Franco Montoro, a 9 de julho de 1962, onde é feita a ampla defesa das "reformas estruturais (...). Reformas de base como a reforma agrária, a reforma urbana, reforma da estrutura da empresa econômica, reforma eleitoral, reforma administrativa, reforma bancária, reforma tributária. Todas elas orientadas no sentido de serem instrumento para a promoção da justiça e a eliminação destas desigualdades". 
Via voltadas para reformas estruturais, talvez sob influência da produção teórica da "escola cepalina", ${ }^{24}$ da qual muitos pedecistas estavam se aproximando. A partir deste momento, o partido precisou demonstrar estar na defesa dos países subdesenvolvidos, daí propor no programa de 1961, "a composição de um bloco de países latino-americanos voltados contra as opressões do imperialismo". Ganhou espaço, também, a busca da independência diplomática e da soberania das nações, inclusive das ditas do terceiro mundo, como demonstra a defesa da igualdade entre os Estados nacionais na ONU, o que decorreria na suspensão do direito de veto concedido às grandes potências. Com este espírito, o deputado federal Euzébio Rocha, a 29 de setembro de 1961, saudou o governo de Goulart por desenvolver, aos seus olhos, uma política externa independente e, inclusive, por manter relações comerciais com os países "que constituem o chamado Bloco Socialista". 25

Ambicionando apresentar-se em oposição ao imperialismo, a Terceira Via do PDC propunha que a Petrobras (Petróleo Brasileiro S/A), fosse entendida pela sociedade como um dos instrumentos de libertação econômica nacional. Com seus ouvidos bem atentos aos alaridos vindos de muitos movimentos sociais, principalmente o estudantil, o sindical e o dos trabalhadores rurais, o PDC passou, portanto, a realinhar-se mais decisivamente na defesa da intervenção do Estado na economia, bem como se aproximou de propostas que indicavam uma maior sensibilidade com as causas populares. Demonstração disso era seu novo programa pregar o "combate à concentração da propriedade em mãos de uma minoria" e a

24 A Comissão Econômica para a América Latina (Cepal) era um organismo da Organização da Nações Unidas (ONU), preocupado com o desenvolvimento econômico desta parte do continente. "Escola cepalina" foi o nome dado aos que defendiam as teses da Cepal. Em resumo, expressavam que a América Latina possuía um atraso estrutural em seu desenvolvimento, e que este só seria superado com a intervenção estatal na economia, principalmente por meio da formação de poupança interna, a qual financiaria o desenvolvimento industrial nacional.

25 Paulo G. Fagundes Vizentini, ao analisar a política externa brasileira entre os anos $1951 \mathrm{e}$ 1964, sustenta que: "Apesar das diferenças existentes entre o nacional-desenvolvimentismo populista de Getúlio Vargas, o desenvolvimentismo associado de Kubitschek, e a Política Externa Independente de Jânio Quadros e João Goulart, bem como das particularidades que marcaram o contexto histórico de cada uma, esses projetos possuem acentuados traços em comum e apresentam uma continuidade. (...) A política externa desses três períodos apresenta um aprofundamento contínuo, que atinge a sua forma superior com a Política Externa Independente (PEI)" (VIZENTINI, Paulo G. Fagundes. Política exterior e desenvolvimento (1951-1964) : o nacionalismo e a politica externa independente. In: Revista Brasileira de História, São Paulo: ANPUH/ Marco Zero, v. 14, n. 27, p.99, 1994. A PEI seria caracterizada por cinco pontos principais: ampliação do mercado externo dos produtos brasileiros por meio da redução tarifária na América Latina e da intensificação das relações comerciais com todas as nações, mesmo as socialistas; formulação autônoma de planos de desenvolvimento econômico, para fugir das imposições do Fundo Monetário Internacional (FMI); coexistência pacífica, desarmamento geral e progressivo; autodeterminação dos povos e não intervenção de países em assuntos internos de outros; apoio à emancipação completa dos territórios não-autônomos (ver VIZENTINI, op. cit., 1994.). Identificamos, portanto, que a reformulação programática do PDC vinculou-se estreitamente com a PEI. 
"necessidade de uma reforma agrária e de uma reforma na estrutura da empresa econômica". A reforma agrária era entendida como a eliminação do latifúndio e do minifúndio improdutivo com a redistribuição da propriedade rural. Num extremo dentro do partido, Euzébio Rocha chegou a dizer, a 25 de agosto de 1961, que "somos pela reforma agrária e estamos interessados em conhecer de perto os propósitos das ligas camponesas sob a chefia do deputado Julião". ${ }^{26}$

A reforma agrária tinha um papel especial no conjunto das reformas de base, tornando-se algo de crucial importância política no início dos anos $60 .{ }^{27} \mathrm{O}$ grande debate era se haveria ou não alteração no artigo 141 da Constituição de 1946, o qual previa indenizações em dinheiro para desapropriações visando a reforma agrária, limitando em muito as possibilidades dos cofres públicos em arcar com uma alteração da estrutura agrária na amplitude que as reformas de base sugeriam; lembramos, aliás, que este artigo é oriundo de uma emenda de Arruda Câmara, ainda quando deputado constituinte.

Diante dessas questões, sob o ponto de vista discursivo, sublinhamos que a Terceira Via pedecista foi favorável à alteração do artigo 141 . Surpreendentemente, até o próprio Arruda Câmara, a 5 de julho de 1962, alinhado com o seu partido, expôs que advogava "estas reformas de base, inclusive a reforma agrária, até com a modificação do artigo 141, parágrafo 16”. Infelizmente, não pudemos apurar a que custo político essa mudança se deu, todavia inferimos ter sido esta a forma que Arruda Câmara encontrou para enfrentar as pressões políticas vindas das Ligas Camponesas; afinal, era Pernambuco, o mesmo estado do pedecista, a base política de Francisco Julião, o grande líder das Ligas. Mas coube ao pedecista Plínio de Arruda Sampaio articular uma emenda

26 Euzébio Rocha se referia ao deputado federal pelo PSB de Pernambuco, Francisco Julião, líder das Ligas Camponesas. Caio Navarro de Toledo, assim as define: "As Ligas Camponesas nasceram da resistência - muitas vezes armada - dos foreiros (pequenos agricultores e não proprietários) contra a tentativa de expulsão das terras onde trabalhavam, movida pelos proprietários; de 1959 a 1962, as Ligas tiveram uma acelerada expansão em todo o Nordeste. As Ligas contestavam, abertamente, a dominação política e econômica a que estavam secularmente submetidas as massas rurais. Em algumas localidades, ocorreram conflitos armados entre 'camponeses' e proprietários de terra; lideranças camponesas serão perseguidas e assassinadas a mando dos latifundiários, alarmados com a politização das massas rurais" (TOLEDO, Caio Navarro de. O governo Goulart e o golpe de 64. São Paulo: Brasiliense, 1983. p. 77).

27 Para Toledo, a reforma agrária tinha importância na estabilidade, ou instabilidade, política da época por dois motivos principais: "De um lado, era preciso aumentar a produção agrícola (alimentos que suprissem as demandas da população urbana em crescimento; matérias-primas para a expansão industrial etc.), ao mesmo tempo que se buscava criar um mercado interno mais amplo para os bens manufaturados. De outro lado, prevendo-se situações incontroláveis de tensões e distúrbios sociais, propunha-se uma melhor distribuição da terra (em mãos de um reduzido número de latifundiários e freqüentemente mantida de forma improdutiva)" (TOLEDO, op. cit., p. 54). A dimensão das discussões sobre a reforma agrária no período podem ser vistas em: BOTAS, Paulo Cezar Loureiro. A benção de abril: "Brasil Urgente" - memória e engajamento católico no Brasil (1963-64). Petrópolis: Vozes, 1983. p. 46-90. 
constitucional que alterava o artigo 141, indicando que as indenizações para os desapropriados passariam a ser mediante títulos da Dívida Pública da União, resgatáveis em vinte anos e em prestações anuais. ${ }^{28}$ Portanto, o teor da Terceira Via foi, para esse contexto, profundamente favorável às reformas de base.

Quanto às empresas multinacionais aqui instaladas, algo tão debatido no Brasil da década de 60, o PDC também esteve atento em ligar sua Terceira Via aos anseios de diversos setores que reivindicavam o controle sobre as remessas de lucros. Propunha, em seu programa de 1961, também,

a aprovação de uma lei antitruste que confiará ao poder público a faculdade ampla de combater e eliminar os quistos de exploração constituídos pela concentração do poder econômico e pela sua interferência no mercado produtor e no consumidor.

A organização da empresa nacional deveria propiciar a participação dos trabalhadores nos lucros, na propriedade e na sua gestão. Dentro desta perspectiva de intervenção do Estado na economia, nem Arruda Câmara pode resistir. A 29 de maio de 1961, apoiou o controle do aumento dos preços dos remédios proposto pelo governo federal. Deputados federais pedecistas defenderam, mesmo, a encampação da Companhia Paulista de Estradas de Ferro (Aniz Badra, a 2 de junho de 1961) pelo governo paulista de Carlos Alberto Carvalho Pinto, e a da Light, empresa de distribuição e geração de energia elétrica do Rio de Janeiro (Euzébio Rocha, a 27 de setembro de 1961).

Também adquiriu grande importância para atuação do PDC a mudança do limite de isenção para o imposto de renda, no que era defendida a implantação de um caráter fortemente progressivo; entretanto, se pretendia isentar quem recebesse até cinco salários mínimos. Franco Montoro foi quem mais se dedicou à tarefa de limitar o imposto de renda para esta faixa salarial.

Vemos, a partir desses dados, que as profundas discussões por que a sociedade brasileira passou a partir de meados da década de cinqüenta, principalmente no que tange ao modelo de desenvolvimento, levaram pedecistas a assumirem, em seu programa e em seus discursos, uma Terceira Via que indicava a necessidade de reformas mais profundas nos diversos campos sociais. Além

28 Segundo Paulo Cezar Loureiro Botas: “O PSD reagia contra esta Emenda propondo a expropriação das propriedades de menos de 500 hectares em dinheiro. Acima disto poderiam ser em títulos de dívida pública (...) Isto eliminaria a possibilidade de desapropriar para constituir cinturões verdes nas grandes cidades. As propriedades próximas de capitais eram em geral de menos de 500 hectares. Eliminaria a possibilidade de intervir ao longo das estradas existentes. Ao largo das áreas equipadas" (BOTAS, op. cit., p. 78). 
do que, este redirecionamento de sua posição nos permite dizer que estavam de olhos bem abertos às possibilidades de conquistas eleitorais surgidas com a desestabilização do sistema político institucional e advindas da crise que passou a se instaurar na aliança entre o PSD e o PTB. ${ }^{29}$

Outros campos importantes, como o das questões mais estritamente políticas e das relações trabalhistas, também tiveram a atenção na reformulação programática. Sobre as relações de trabalho, propuseram a sindicalização rural, o direito de greve e o estabelecimento de legislação trabalhista para o homem rural, contrapondo-se programaticamente aos grandes proprietários rurais. Essas questões colocavam o partido praticamente em rota de colisão com a UDN, não podendo ser caracterizado como um de seus satélites. ${ }^{30}$

Quanto aos assuntos ligados à organização da estrutura política do país, o novo programa trouxe para a Terceira Via pedecista uma concepção de democracia institucional semelhante àquela que Jean-Marie Mayeur qualificou como sendo da DC; abrangia-se algo mais que as relações dos eleitores com o Estado via partido e não se dimensionava seu sentido tanto pela evangelização e hierarquia, como no programa anterior. Os pedecistas entendiam que a intervenção do poder público deveria dar-se de forma plural e descentralizada, respeitando e fortalecendo "os grupos sociais intermediários, como a família, o Município, o sindicato, a empresa, a escola, a cooperativa e outras, que não poderão ser absorvidos ou eliminados pelo poder centralizador do Estado". Viram, ainda, a necessidade da reformulação do sistema eleitoral, pois este estaria "burlado pelos interesses de grupos econômicos nacionais e estrangeiros" que com seu poder econômico determinariam o resultado das eleições; a mudança era necessária "para que as campanhas eleitorais não dependam do poderio financeiro, cabendo ao Estado divulgar o nome dos candidatos, em termos de igualdade". No aspecto das reformas eleitorais, ressaltamos que o deputado Arruda Câmara, em junho de 1961, preocupado com a ampliação da base eleitoral brasileira, tomou a palavra no Congresso

29 As constatações de Benevides contribuem para uma melhor reflexão deste processo: "a associação Forças Armadas/Congresso tem seu momento de ruptura no plano da ordem, na medida em que as contradições no interior da aliança PSD/PTB e em cada partido se agravam com o radicalismo do PTB, por sua identificação com as reivindicações populares; setores do Exército passam a se preocupar seriamente com o envolvimento do PTB 'janguista' com teses de 'esquerda' e com os comunistas” (BENEVIDES, O governo Kubitscheck..., p. 249).

30 A própria Benevides, ao estudar o PTB paulista, indica um dado que demonstra o fortalecimento do PDC, mesmo em relação a UDN. Em 1960, em São Paulo, o partido tinha "272 diretórios, mais do que a UDN" (BENEVIDES, O PTB e o trabalhismo..., p. 66). Infelizmente não pudemos apurar o número de diretórios udenistas, entretanto, seja qual for, mesmo que próximo ao pedecista, é uma demonstração de equilíbrio entre eles, pelo menos em São Paulo. 
Nacional para defender o voto dos analfabetos, praças, soldados e cabos das Forças Armadas, bem em sintonia com as reformas do período.

Em fins de março de 1963, na cidade paulista de Águas do Prata, outra convenção do PDC confirmou a sua Terceira Via numa linha de defesa das reformas de base. As tendências conservadoras intrapartidárias não conseguiram impedir que Paulo de Tarso Santos e Plínio de Arruda Sampaio tivessem sucesso em eleger Ney Braga, contra Franco Montoro, presidente nacional do partido. Eles estavam convencidos de que o governador do Paraná, pelo que sua administração vinha apresentando, estava em inteiro acordo com as suas idéias reformistas, ao contrário de Franco Montoro, que era mais moderado nestas questões.

Não nos furtamos a dizer, ainda, que todo este intrincado quadro de mudanças em que o PDC estava inserido teve como resolução a construção de uma Terceira Via que se aproximou do movimento internacional Economia e Humanismo, surgido pelas mãos do padre francês Louis-Joseph Lebret. ${ }^{31}$ No Brasil, o padre dirigiu a Sociedade para Análise Gráfica e Mecanográfica Aplicada aos Complexos Sociais (SAGMACS). Segundo Dennison de Oliveira,

310 padre Louis-Joseph Lebret definiu economia humana "enquanto pesquisa, como a disciplina, especulativa e prática, da passagem, para uma determinada população, de uma fase menos humana para uma fase mais humana, segundo o ritmo mais rápido possível, com o custo financeiro e humano o menos elevado possível, sem esquecer a solidariedade que deve existir entre todas as populações” (LEBRET, Louis-Joseph. Manifesto por uma civilização solidária. São Paulo: Duas Cidades, 1962. p. 16, com grifos no original). Para que esta elevação se estabelecesse seria necessária "uma planificação desde as unidades territoriais elementares até o conjunto mundial. Não se trata, evidentemente, de propugnar um modo único de planificação, mas, pelo contrário, uma grande variedade, levando-se em conta, em cada caso, as possibilidades, as estruturas atuais, os tipos de necessidade, os estágios técnicos e culturais, a qualidade e intensidade dos esforços espontâneos ou a incrementar" (p. 89, sem grifos no original). Louis-Joseph Lebret faz, como a DC, críticas ao capitalismo e ao comunismo. Quanto ao capitalismo, ele seria, principalmente em sua primeira fase liberal, um regime marcado pelo "direito exclusivo para os detentores de capital de decidir sobre a orientação dos investimentos decorrentes do lucro. É um regime incapaz de conduzir à satisfação ordenada das necessidades. É um regime fatalmente criador de exploração e opressão, contra as quais não podem deixar de existir reações de camadas sociais e de povos, através de um sistema complexo de tensões mais ou menos lentas ou destruidoras" ( p. 27). Quanto ao comunismo, a maior falha seria a "sua concepção da pessoa. Para ele, o homem individual pouco representa. O homem conta apenas pelo esforço de que é capaz na edificação do comunismo, tal qual a concebe o grupo que se apodera do poder. A verdade perde sua natureza absoluta. A inteligência é fundamentalmente comprometida. A violência torna-se universal. A selvageria aperfeiçoada e tecnicamente calculada é, em definitivo, muito semelhante à que foi praticada na primeira fase do capitalismo" (p. 38). Todavia, a humanidade deveria se inspirar na planificação econômica e na nacionalização de alguns setores feitas pelos soviéticos, como forma de acelerar o seu desenvolvimento (p. 40-41). Notamos nos elementos apontados por Rogério Luiz de Souza como característicos da DC brasileira, uma profunda similaridade com os pressupostos de Economia e Humanismo. Segundo o autor, para o PDC "estava claro que o Estado deveria conhecer a fundo as contradições do sistema e da sociedade, firmando-se como um Estado Tecnoburocrático. O serviço especializado de controle de preços e de fluxo de produção e a supervisão de um Estado técnico diminuiriam os riscos e os conflitos de classe, onde apareceria planejando o desenvolvimento nacional em bases técnico-científicas" (SOUZA, op. cit., p. 65). 
esse grupo se destinava a forjar uma mentalidade de planejamento na periferia do capitalismo que fosse capaz de erradicar os piores excessos do populismo e do próprio capitalismo, contribuindo para afastar o perigo do comunismo, cuja atuação era tida como mais eficaz em áreas pauperizadas. ${ }^{32}$

Entendemos que os posicionamentos desta corrente política podem ser considerados quase que uma transcrição literal dos objetivos da DC de constituir-se como uma Terceira Via entre o capitalismo e o socialismo. Todavia, para uma apreciação mais conclusiva sobre estas correlações, necessitamos de pesquisas de maior fôlego o que, até o momento, não localizamos.

Novamente sobre o PDC, e tendo por base o quadro analisado anteriormente, notamos o aumento, ainda que com idas e vindas, da influência da sua Terceira Via em nível nacional. Se, para as eleições de 1954, somente dois pedecistas se elegeram, Arruda Câmara por Pernambuco e Antônio Queiroz Filho por São Paulo, essa escassez não foi duradoura, pois para a legislatura 1959-1963 o crescimento já pode ser constatado de modo mais concreto. Foram eleitos sete pedecistas: Arruda Câmara por Pernambuco; Hélio Ferreira Machado pela Bahia; Paulo de Tarso Santos, Franco Montoro, Geraldo Corrêa de Carvalho e José Menck por São Paulo; e Ney Braga pelo Paraná. Nesta legislatura, Wagner Estelita, eleito por Goiás, saiu do PSD e se filiou ao PDC a 6 de setembro de 1961, acompanhando o realinhamento e dando a seu novo partido a representação de oito deputados. Naquela quadra histórica, um acontecimento demonstra a tentativa do PDC em firmar sua Terceira Via no quadro político nacional de maneira independente dos três grandes partidos. Franco Montoro, a 10 de março de 1961, expôs o seguinte na Câmara dos Deputados: "Quero levar ao conhecimento da Mesa que acaba de se constituir, nesta casa, o bloco parlamentar PR-PDC-PTN-PSB". O partido, portanto, não se importava em agrupar-se mesmo junto àqueles que se entendiam como socialistas, demonstrando que não era um simples anciliar da UDN - ao contrário do que afirmam diversos autores - e buscava se colocar como uma força política no quadro partidário nacional.

32 OLIVEIRA, Dennison. Curitiba e o mito da cidade modelo. Curitiba: Editora UFPR, 2000. p. 69. Outros dois autores se remetem a influência do padre Louis-Joseph Lebret na política brasileira. Emanuel de Kadt aponta que movimentos e grupos brasileiros como a JUC e a Ação Popular se pautavam por considerações deste padre (KADT, Emanuel de. Paternalism and populism: Catholicism in Latin America. In: The Journal of Contemporary History. Londres: The Institute of Contemporary History, 1967, p. 99-102. v. 2, n. 4.). Rogério Luiz de Souza também faz menção à ação de Lebret junto a SAGMACS (SOUZA, op. cit., p. 95). 
No momento em que o debate político nacional ganhou maior dinamismo, no início dos anos 60, a arena política ficou mais favorável ao PDC. Desta feita, as eleições de 1962 deram outra demonstração de que o potencial político de sua Terceira Via estava se transformando em efetivo preenchimento de espaços políticos, pois o partido pode contar com vinte deputados e um senador. ${ }^{33}$

Porém, este crescimento não isentou seus membros de ambigüidades. No que se refere, por exemplo, a dita reforma do sistema eleitoral, algo tão defendido pelos pedecistas, e aos recursos financeiros de suas campanhas ou ao tipo de auxílio econômico, algumas constatações são significativas. Nessa questão, nem sempre as suas ações estiveram em concordância com o conteúdo programático do partido. Apesar de programaticamente terem se postado contrários ao financiamento de campanhas eleitorais ou políticas por parte de empresas, muitos dos correligionários, e não de pouca importância política, estiveram intimamente ligados ao Instituto de Pesquisas e Estudos Sociais e ao Instituto Brasileiro de Ação Democrática (Complexo Ipes/Ibad). É importante destacarmos que o objetivo destes dois institutos, Ipes e Ibad, era articulado e muito claro: "agir contra o governo nacional-reformista de João Goulart e contra o alinhamento de forças sociais que apoiavam a sua administração". ${ }^{34}$ Entre os membros do PDC que possuíram vínculos com estes institutos estiveram o governador do Paraná, Ney Braga, o deputado estadual pela Guanabara, Gladstone Chaves de Mello, o sindicalista Rômulo Marinho, Antônio Cesarino Júnior, Gabriel Chaves de Mello, Euclides Triches; ${ }^{35}$ o governador de São Paulo, Carvalho Pinto, francamente apoiado pelo PDC, também recebia recursos destes institutos. Tudo indica que esta disposição em desestabilizar o governo de

33 Eram estes, segundo seus respectivos estados, os congressistas do PDC eleitos em 1962: Bahia: José Werneck; Guanabara: Juarez Távora; Paraná: Francisco Accioly Rodrigues da Costa Filho, Emílio Hoffmann Gomes, José Richa e Minoro Miyamoto; Pernambuco: Arruda Câmara; Rio de Janeiro: Geremias de Matos Fontes; Rio Grande do Norte: Odilon Ribeiro Coutinho; Rio Grande do Sul: Cid Furtado e Euclides Triches; São Paulo: Aniz Badra, Athié Jorge Coury, Franco Montoro, Francisco Scarpa, José Menck, Paulo de Tarso Santos, Plínio Soares de Arruda Sampaio, Teófilo Ribeiro de Andrade Filho e José Henrique Turner. O senador eleito foi Arnon de Farias Melo, por Alagoas.

34 DREIFUSS, op. cit., p. 161.

35 Ney Braga contava com o Ibad para levantar apoio para suas campanhas políticas (DREIFUSS, op. cit., p. 314; 334). Gladstone Chaves de Mello participava de muitas atividades organizadas pelo Ibad como, por exemplo, o Simpósio sobre Reforma Agrária, realizado em abril de 1961 (p. 241). Carvalho Pinto tinha um programa na TV Cultura, sobre sua avaliação do momento político, patrocinado pelo Ipes e pelo Ibad (p. 247). Rômulo Marinho era um sindicalista que organizava seminários anticomunistas financiados pelo Ipes (p. 318). Antônio Cesarino Júnior era um dos responsáveis do complexo Ipes/Ibad para formular teses a serem apresentadas por deputados no Congresso (p. 244). Gabriel Chaves de Mello, irmão de Gladstone Chaves de Mello, era um ativista do Ibad (p. 104). Euclides Triches recebeu apoio do Ibad nas eleições de 1962 p. 334). Em São Paulo, também tiveram apoio do complexo Ipes/Ibad os deputados federais pelo PDC José Menck, Aniz Badra e José Henrique Turner (p. 335). 
Goulart não era algo restrito à DC em sua versão brasileira, pois, entre as agências que financiaram o complexo Ipes/Ibad estava, por exemplo, a Konrad Adenauer Stiftung, órgão da União Democrata Cristã da Alemanha.

Para maior clareza sobre a importância de relacionarmos alguns pedecistas com esses acontecimentos, vale lembrar que Dreifuss é explícito quando trata das motivações que levavam os dois institutos a apoiar financeiramente algum político: o financiamento se dava em troca da posição de cada um contra as reformas estruturais reivindicadas pelo Executivo de Goulart. Demonstrando articulação com essas posições contrárias às reformas, o pedecista Aniz Badra, a 7 de agosto de 1961, expôs que o Congresso Nacional não deveria ter pressa em votar a lei antitruste; e destacou o editorial do jornal $O$ Estado de São Paulo, ressaltando "a conveniência de se reduzir a intervenção estatal na economia e mesmo a participação do Estado na organização e direção de empresas produtoras".

\section{Considerações finais}

Em referência aos pressupostos políticos do PDC, enunciados tanto nos programas quanto nos discursos, identificamos um corte quanto ao teor de sua Terceira Via: 1945/1954-1955 e 1954-1955/1963-1964. Desde a fundação do partido, até por volta de meados dos anos 50, suas posições políticas confirmaram a tese que o entende como pequeno partido oposicionista ao núcleo PSD/PTB. Daí possuírem posições por vezes ambíguas, pois se, de um lado, ainda que timidamente, postulavam a intervenção do Estado na economia, por outro, a conjuntura pós-Vargas empurrou-os para próximo da UDN. Sua Terceira Via, portanto, não foi muito definível numa situação que colocava os pedecistas assaz como defensores do liberalismo econômico e do anticomunismo, o que era bem personificado por Arruda Câmara. Isso os localizava quase que como uma espécie de tropa de choque da ala udenista mais liberal - esse foi o caso, por exemplo, da questão do controle público dos aluguéis, defendido por um udenista, Paulo Sarasate, em 1946, mas duramente combatido por Arruda Câmara. Também não puderam fugir da percepção autoritária sobre democracia predominante no período. Averiguamos que a noção de democracia dos pedecistas esteve limitada por um forte conteúdo que pressupunha a evangelização e a hierarquia, tudo bem ao gosto de um 
contexto em que a elite política sentiu a necessidade de buscar estabelecer um pluralismo partidário controlado e disciplinado.

No primeiro momento do corte temporal que estabelecemos, ou seja, período que se situou aproximadamente entre 1945 e 1954-1955, é factível dizer que o PDC possuía uma atuação pouco expressiva e marcada por alianças em que não exerciam peso político considerável; tinha uma atuação oposicionista aproximada da linha de atuação de Carlos Lacerda, como diria mais tarde Ney Braga. Uma indicação disso foi, por exemplo, estar o partido contra a construção de Brasília, a menina dos olhos do Governo Kubitschek, inclusive fazendo muitas denúncias. Mas não custa lembrar que quando este Presidente decidiu romper com o FMI contou com o apoio do PDC.

Quando o sistema partidário brasileiro sofreu o realinhamento, o que se deu a partir de meados dos anos 50, o PDC viu a necessidade de reformular o conteúdo de seu programa e pôde dar uma melhor definição a sua Terceira Via. Este processo conformou-se a partir da virada da década de 50, quando o partido incorporou lideranças como Franco Montoro e Paulo de Tarso Santos, em São Paulo, e Ney Braga, no Paraná, adquiriu maior dinamismo político e partiu para a alteração de seu programa. No campo interno, portanto, este processo foi alçado pela VD, que conseguiu, principalmente junto e com o apoio da JDC, dar ao PDC uma maior abertura aos ventos do reformismo. Iniciouse aí, para nós, o segundo momento dos pedecistas, 1954-1955/1963-1964, quando no terreno intrapartidário, o grupo advindo da VD teve sucesso em fornecer ao partido uma Terceira Via vinculada às propostas reformistas, o que proporcionou ao PDC um melhor alcance eleitoral. Diríamos, também, que nesse momento a sua Terceira Via se tornara atraente para agentes políticos de duas posições: de um lado aqueles insatisfeitos com a atuação do PTB que se radicalizava, e estariam procurando espaço em uma alternativa mais palatável e dentro da ordem, como foi o caso de Joel Presídio de Figueiredo; de outro lado, políticos insatisfeitos com UDN e sua linha golpista, claramente voltada aos interesses do grande capital monopolista, como no caso de Antenor Mourão Bógea.

Nesse sentido, não podemos nos esquecer que se a aliança PSD/PTB sustentou-se de tal forma que por um bom tempo impediu não só o efetivo crescimento do PDC, como de qualquer outro agrupamento partidário, isto não pôde passar ao largo das transformações socioeconômicas pelas quais a sociedade brasileira passou a partir dos anos 50. Portanto, se o sistema políticopartidário impediu estruturalmente uma ascensão eleitoral mais saliente dos pedecistas brasileiros, quando o sistema partidário iniciou uma tendência ao 
realinhamento e a aliança PSD/PTB começou a estremecer, o PDC teve a chance de alçar um crescimento eleitoral mais perceptível. A partir desse momento, a sua Terceira Via passou a se solidificar, desvinculando o partido de sua situação de simples satélite ou ancilar à UDN - estamos, desta forma, discordando das teses que tendem a generalizar o seu papel de satélite udenista para todo o período 1945-1964.

Sendo assim, no início dos anos 60, quando o eleitorado passou a pender para os partidos que defendiam reformas no capitalismo brasileiro, os pedecistas deram um tom mais forte a sua Terceira Via, o que os levou ao reformismo. Era necessário, então, se desvincular dos udenistas e partir para a conquista de um eleitorado mais exigente nos desejos de transformações. Destarte, coube inscreverem em seus discursos e em seu programa uma Terceira Via que se pautava pela defesa de temas que iam desde o controle sobre a remessa de lucros das multinacionais, o fim do latifúndio, a incorporação dos trabalhadores rurais na legislação trabalhista, a sindicalização rural, chegando a propor a composição de um bloco de países latino-americanos que se voltasse contra as opressões dos países imperialistas. E esta mudança de linha política, como vimos, pôde inclusive ser observada no tom dos discursos do notório anticomunista Arruda Câmara.

Porém, apesar da fidelidade programática dos pedecistas poder ser entendida como sendo alta, e o próprio investimento em alterar o programa demonstra isso, devemos ser cuidadosos e perceber que a disposição em implementar sua Terceira Via não era a mesma em todos os correligionários. Afinal, importantes partidários mantiveram relações com o complexo Ipes/Ibad e esses institutos tinham a clara intenção de impossibilitar, a um alto custo político e financeiro, as tão debatidas reformas pretendidas pelo governo Goulart, reformas estas perfeitamente sincronizadas com o novo programa partidário do PDC. 